\title{
HUBUNGAN FLEKSIBILITAS PERGELANGAN TANGAN DAN KOORDINASI MATA TANGAN TERHADAP KETEPATAN SERVIS PENDEK BULUTANGKIS
}

\author{
1Firman Maulana, ${ }^{2}$ Ahmad Alwi Nurudin, ${ }^{3}$ Ardi Agustiansyah Rasyid $\bowtie$ \\ 123Universitas Muhammadiyah Sukabumi \\ $\bowtie$ ardiagustian92@gmail.com
}

\begin{abstract}
ABSTRAK
Penelitian ini bertujuan untuk mengetahui hubungan fleksibilitas pergelangan tangan dan koodinasi mata tangan terhadap ketepatan servis pendek ekstrakurikuler bulutangkis di MTs Negeri 3 Kabupaten Sukabumi. Penelitian ini menggunakan metode kuantitatif dengan pendekatan korelasional. Sampel peneitian adalah perserta ekstrakurikuler di MTs negeri 3 Kabupaten Sukabumi yang berjumlah 15 orang, dengan teknik pengambilan sampel menggunakan purposive sampling. Instrumen yang digunakan dalam penelitian ini meliputi: (1). Tes Fleksibilitas (2). Tes Koordinasi mata tangan (3). Tes ketepatan servis pendek. Hasil penelitian menunjukan bahwa (1). Ada hubungan yang signifikan antara fleksibilitas (X1) dan ketepatan pukulan servis pendek (Y). (2). Ada hubungan yang signifikan antara koordinasi mata tangan (X2) dan ketepatan servis pendek (Y). (3). Ada hubungan yang signifikan antara fleksibilitas (X1) dan koordinasi mata tangan (X2) terhadap ketepatan servis pendek (Y). Berdasarkan hasil perhitungan menggunakan teknik korelasi ganda diperoleh hasil $\mathrm{F}_{\text {hitung }}$ lebih besar dari pada $\mathrm{F}_{\mathrm{tabel}}$, yaitu $\mathrm{F}_{\text {hitung }}(39)>\mathrm{F}_{\text {tabel }}(3,11)$ dengan taraf signifikan 0,05 maka $\mathrm{H}_{1}$ ditolak artinya terdapat hubungan antara fleksibilitas dan kekuatan koordinasi mata tangan terhadap ketepatan pukulan servis pendek dalam permainan bulutangkis pada ekstrakurikuler MTs Negeri 3 Kabupaten Sukabumi. Dan konstruksi secara simultan $\mathrm{R}^{2} \times 100 \%=0,927^{2} \times 100 \%=85,9 \%$ dan sisanya $14,1 \%$.
\end{abstract}

Kata kunci : Fleksibilitas, Koordinasi Mata Tangan, Servis Pendek

\section{ABSTRAC}

This study aims to determine the relationship between wrist flexibility and eye coordination on the accuracy of badminton extracurricular short services at MTs Negeri 3 Sukabumi Regency. This study uses a quantitative method with a correlational approach. The research sample was 15 extracurricular participants at state MTs 3 Sukabumi, with the sampling technique using purposive sampling. The instruments used in this study include: (1). Flexibility Test (2). Hand eye coordination test (3). Short service accuracy test. The results showed that (1). There is a significant relationship between flexibility (X1) and short serve accuracy (Y). (2). There is a significant relationship between hand eye coordination (X2) and short serve accuracy (Y). (3). There is a significant relationship between flexibility (X1) and hand eye coordination (X2) on short serve accuracy (Y). Based on the results of calculations using multiple correlation techniques, the results obtained Fcount is greater than Ftable, namely Fcount (39)> Ftable (3.11) with a significant level of 0.05, H1 is rejected, meaning that there is a relationship between flexibility and strength of hand eye coordination on the accuracy of the stroke short service in badminton at MTs Negeri 3 Sukabumi extracurricular activities. And construction simultaneously R2 × 100\% $=0.9272 \times 100 \%$ $=85.9 \%$ and the remaining $14.1 \%$.

Keywords: Flexibility, Hand Eye Coordination, Short Service Punches

Alamat Korespondensi: Universitas Muhammadiyah Sukabumi

$\triangle$ Email: ardiagustian92@gmail.com
(C) 2020 STKIP Pasundan ISSN2721-5660 (Cetak) ISSN 2722-1202 (Online) 


\section{PENDAHULUAN}

Olahraga merupakan gerak badan yang dilakukan oleh satu orang atau beregu atau kelompok, serta tujuan olahraga yaitu peningkatan kondisi fisik, kemampuan teknik olahraga, pengembangan mental yang akan menjadi olahragawan tangguh (Mardiana, 2014). Menurut Riyandi (2017), Bulutangkis merupakan cabang olahraga yang bisa dimainkan oleh dua ataupun empat orang dengan cara memukul shuttlecock melewati net. Olahraga juga merupakan suatu dari permainan yang ciri khasnya olaharga ditandai dengan kebebasan dan kegiatan suka rela tanpa ada paksaan dan begitu juga olaharaga sejatinya bukan sesuatu yang mendatangkan dalam mewujudkan keteramplian motorik, daya tahan, Salah satu bidang olahraga yang menciptakan keterampilan motoric dan daya tahan,kekuatan,dan kecepatan dalam bulutangkis.

Menurut Werdihartohadi dalam buku "Menjadi Juara Bulutangkis" (2018), Awalnya olahraga mulai dimainkan di india, dan berkembang pesat di inggris pada ke-17. Pada tanggal 5 juli 1934, berdiri federasi bulutangkis dunia dengan Internasional Badminton Federation (IBF) di inggris. Seiring perkembangan bulutangkis sangatlah pesat, olahraga ini merupakan olahraga yang banyak diminati oleh penduduk di Indonesia dari berbagai kalangan. Salah satu bukti banyak di minatinya bulutangkis dapat di lihat dari jumlah bibit pebulutangkis yang ada di Indonesia. Menurut berita pada website liputan6.com (2018) Sebanyak 10.015 bibit pebulutangkis tercatat mampu mengikuti seleksi beasiswa bulutangkis dari seleksi paling awal. Menurut sebuah artikel pada media elektroknik sport tempo.com (2019), jumlah peserta yang di terima pada seleksi tingkat nasional beasiswa bulutangkis jarum juga memiliki peningkatan sejak tahun 2017 hingga 2019 untuk usia 11,13 dan 15 tahun yaitu pada tahun 2017 sebanyak 704 peserta (U-11 dan 13) , 2018 sebanyak 1054 peserta (U-11,13 dan 15) dan 2019 sebanyak 900 peserta ( U-11 dan 13 ). Berdasarkan 2 data di atas terlihat antusias yang cukup banyak terhadap olahraga bulutangkis.

Menurut (Qalbi, Abdurrahman, \& Bustamam, 2016). Bulutangkis yaitu cabang olahraga yang dimainkan oleh pemain single atau double dengan cara memukul shuttlecock melewati bagian atas net. Sedangkan menurut (Aksan, 2012) Olahraga raket adalah dimana olahraga ini dimainkan oleh dua orang ( untuk tunggal) atau dua pasangan (untuk ganda ) yang mengambil posisi berlawanan di bidang lapangan yang dibagi dua oleh sebuah jaring (net). Berdasarkan penjelasan para ahli di atas maka dapat ditarik kesimpulanya bahwa permainan bulutangkis ini merupakan permainan yang menggunakan alat yang dinamakan raket dan shuttlecock karena tidak butuh banyak pemain, yang dimainkan hanya oleh dua orang pemain atau empat orang pemain.

Menjadi seorang pebulutangkis di haruskan bisa memahami dan menguasai berbagai keterampilan dan tehnik dasar, diantaranya cara memegang raket, sikap siap (stance), gerakan kaki (footwork), dan gerakan memukul (strokes). Salah satu tehnik dara lainnya ialah servis, seringkali tehnik ini tidak dapat dilakukan secara baik dan benar sehingga membuat permainan tidak berjalan baik. Permasalahan ini sering terjadi pada Peserta Ektrakurikuler di Mts Negeri 3 kabupaten Sukabumi dimana mereka masih banyak kesalahan dalam melakukan servis pendek karna disaat melukan servis pendek di bagian pergelangan tangan kaku dan posisi disaat akan melakukan servis pendek peserta ekstrakurikuler dimana posisi servis pendek tidak benar.

Pada penelitian ini peneliti melakukan obsesatu tehrvasi pada peserta ekstrakurikuler di Mts Negeri 3 Kabupaten Sukabumi. berdasarkan hasil pengamatan dan latihan langsung terhadap peserta ekstrakurikuler di MTs Negeri 3 Kabupaten sukabumi banyak sekali yang menggunakan teknik servis pendek untuk memulai permainan, namun dalam pelaksanaa melakukan servis pendek banyak sekali dilakukan dengan tehnik yang kurang tepat. Berdasarkan latar belakang diatas maka peneliti tertarik untuk melakukan penelitian mengenai penguasaan teknik dasar servis pendek dalam permainan bulutangkis. Hasil penelitian ini diharapkan hasil penelitian ini mampu miningkatkan keterampilan fleksibilitas antara pergelangan tangan dan mata sehingga mampu menghasilkan servis pendek baik dan benar. 


\section{METODE}

Menurut winarno (dalam Mohammad, D.M.2018: 21) berpendapat bahwa "metode penelitian adalah pengetahuan yang diperoleh dari penelitian dapat berupa fakta, konsep,generalisasi dan teori yang meyakinkan manusia dapat memahi phenomena dan memecahkan masalah yang dihadapi". Adapun jenis penelitian ini adalah penelitian kuantitatif dengan menggunakan analisis korelasional atau penelitian hubungan untuk mengetahui sebab dan akibat. Secara spesifik peneliti menggunakan metode kualitatif untuk mengetahui bahwa ada tidaknya hubungan fleksibilitas pergelangan tangan dan koordinasi mata tangan terhadap ketepan servis pendek dalam permanian bulutangkis pada ektrakulikuler bulutangkis di Mts Negeri 3 Kabupaten Sukabumi.

Desain penelitian yang digunakan didalam penelitian ini adalah one group pretests postes desain petama-tama peserta ekxtrakulikuler yang mengikuti pemnbelajaran yang diberikan (pretests) untuk mengetahui keterampilan pukulan servis pendek, kemudian di berikan perlakuan (treatment) yaitu berupa pembelajaran setelah itu diberikan (posttest). menurut Mia Kusumawati (2015: 33) penelitian hubungan atau (asosiatif) dapat berupa hubungan simetris, kausal (sebab akibat), atau hubungan timbal balik. Dalam klasifikasi penelitian ini, peneliti tentang hubungan $\mathrm{X}$ dengan $\mathrm{Y}$ dapat digolongkan menjadi statistik korelasional, yang menghubungkan dua variabel ata $u$ lebih. Penelitian ini dilaksanakan pada tanggal 9 November yang betempatan di GOR Sampora Kabupaten Sukabumi. Mulai dari jam 2 siang dan hari pelaksanaan senin / kamis. Populasi dalam penelitian ini adalah peserta Ekstrakulikuler Mts Negeri 3 Kabupaten Sukabumi yang sudah di random, dmupulaniambil sample berjumlah 15 orang yaitu kelas VIII. Adapun kerangka berfikir yang dapat dikembangkan dalam penelitian ini adalah sebagai berikut:

a. Ada hubungan koordinasi mata tangan dalam permainan Bulutangkis pada Ekstrakurikuler Bulutangkis di MTs Negeri 3 Kabupaten Sukabumi 2019

b. Ada hubungan fleksibilitas pergelangan tangan terhadap ketepatan servis pendek dalam permainan Bulutangkis pada Ekstrakurikuler Bulutangkis di MTs Negeri 3 Kabupaten Sukabumi 2019

\section{HASIL PENELITIAN}

Dari kegiatan penelitian yang sudah dilaksanakan sebanyak satu kali dengan dilakukan pengambilan data tes fleksibilitas pergelangan tangan dan koordinasi mata tangan terhadap ketepatan pukulan servis pendek lalu mengobservasi hasilnya dalam ekstrakurikuler di MTS N 3 Kabupaten Sukabumi dengan jumlah peserta 15 orang. Pada saat dilaksanakan pengetesan ditemui adanya keterkaitan fleksibilitas pergelangan tangan dan koordinasi mata tangan terhadap servis pendek yang cukup baik. Hal ini dapat diketahui dari hasil tes dan pengukuran pada peserta tes tersebut. dalam penelitian ini menghasilkan satu data mentah yang dari dua variable bebas dan satu variable terikat. Variable bebas dalam penelitian ini adalah fleksibilitas pergelangan tangan dan koordinasi mata tangan, dan variable terikat dalam penelitian ini adalah servis pendek, dari hasil tersebut meliputi data rat-rata dan standar deviasi, hasil korelasi antara fleksibilitas pergelangan tangan dan koordinasi mata tangan, terhadap ketepatan pukulan servis pendek. Dari pengolahan dan analisis data tersebut diperoleh nilai-nilai yang dapat dilihat pada tabel sebagai berikut ;

Tabel 1. Hasil penghitungan data rata-rata dan standar deviasi

\begin{tabular}{cccc}
\hline & X1 & X2 & Y \\
\hline Rata-rata & 33,15 & 12,69 & 57,02 \\
\hline Standar Deviasi & 5,75 & 3,56 & 7,55 \\
\hline
\end{tabular}


Tabel 2. Diagram batang hasil penghitungan data rata-rata dan standar deviasi

\begin{tabular}{cccc}
\hline & X1 & X2 & Y \\
\hline Rata-rata & 33,15 & 12,69 & 57,02 \\
\hline Standar Devisiasi & 5,75 & 3,56 & 7,55 \\
\hline
\end{tabular}

Tabel 3. Hasil korelasi antara fleksibilitas pergelangan tangan dan koordinasi mata tangan, terhadap ketepatan pukulan servis pendek

\begin{tabular}{|c|c|c|c|}
\hline Sumber & Rata-rata & $\mathbf{R}_{\text {hitung }}$ & Kesimpulan \\
\hline $\mathbf{X}_{1}$ & 33,15 & \multirow[t]{3}{*}{0,927} & \multirow{3}{*}{$\begin{array}{c}\text { Tingkat hubungan kuat dan } \\
\text { tinggi }\end{array}$} \\
\hline $\mathbf{X}_{2}$ & 12,69 & & \\
\hline $\mathbf{Y}$ & 57,02 & & \\
\hline
\end{tabular}

Berdasarkan deskripsi tabel 4.3 hubungan antara fleksibilitas pergelangan tangan dan koordinasi mata tangan terhadap ketepatan pukulan servis pendek dalam permainan bulutangkis pada peserta ekstrakurikuler MTs Negeri 3 kabupaten Sukabumi tergolong kuat dan tinggi. Konstruksi secara simultan R2 x 100\% = 0,9272 x 100\% = 85,9\% dan sisanya $14,1 \%$ ditentuk oleh variabel lain.

Tabel 4. Hasil uji signifikansi menggunakan $\mathrm{F}_{\text {hitung }}$

\begin{tabular}{|c|c|c|c|c|c|}
\hline Sumber & Rata-rata & $F_{\text {hitung }}$ & $F_{\text {tabel }}$ & $\alpha$ & Kesimpulan \\
\hline $\mathbf{X}_{1}$ & 33,15 & 39 & 3,11 & 0,05 & $\mathrm{H}_{1}$ diterima \\
\hline$X_{2}$ & 12,69 & & & & Ada hubungan yang \\
\hline $\mathbf{Y}$ & 57,02 & & & & signifikan \\
\hline
\end{tabular}

Keterangan:

$\mathrm{X}_{1}$ : Hasil pengumpulan data variabel fleksibilitas pergelangan tangan

$\mathrm{X}_{2}$ : Hasil pengumpulan data variabel koordinasi mata tangan

Y : Hasil pengumpulan data variabel ketepatan pukulan servis pendek

Tabel 5. Hasil uji signifikansi menggunakan $\mathrm{F}_{\text {tabel }}$

\begin{tabular}{cccccc}
\hline Sumber & Rata-rata & $\mathbf{F}_{\text {tabel }}$ & $\mathbf{F}_{\text {hitung }}$ & $\boldsymbol{\alpha}$ & Kesimpulan \\
\cline { 1 - 2 } $\mathbf{X}_{\mathbf{1}}$ & 33,15 & 3.11 & 39 & 0,05 & $\mathrm{H}_{0}$ ditolak \\
\cline { 1 - 2 } $\mathbf{Y}$ & 12,69 & & & & Tidak ada hubungan yang signifikan \\
\cline { 1 - 2 } & 57,02 & & & & \\
\hline
\end{tabular}

Keterangan:

$\mathrm{X}_{1}$ : Hasil pengumpulan data variabel fleksibilitas pergelangan tangan

$\mathrm{X}_{2}$ : Hasil pengumpulan data variabel koordinasi mata tangan

Y : Hasil pengumpulan data variabel ketepatan pukulan servis pendek

Berdasarkan hasil korelasi tabel 4.4 diperoleh bahwa Fhitung lebih besar dari pada Ftabel yaitu Fhitung (39) > Ftabel $(3,11)$ dengan taraf signifikansi 0,05. Maka dapat dinyatakan H1 ditolak, artinya ada hubungan yang signifikan. Dengan mendapatkan hasil perhitungan Rx1x2y sebesar 0,927 dengan kategori tergolong kuat dan tinggi. Dan konstruksi secara simultan R2 x $100 \%=0,9272 \times 100 \%=85,9 \%$ dan sisanya $14,1 \%$. Artinya penguasaan fleksibilitas pergelangan tangan dan koordinasi mata tangan memberikan kontribusi terhadap ketepatan pukulan servis pendek dalam permainan bulutangkis sebesar $85,9 \%$ dan sisanya $14,1 \%$ oleh variabel lain. 


\section{PEMBAHASAN}

\section{Hubungan antara fleksibiltas pergelangan tangan terhadap ketepatan servis pendek}

Salah satu komponen kondisi fisik saat melakukan pukulan servis pendek adalah fleksibilitas pergelangan tangan, berdasarkan hasil penelitian tersebut fleksibilitas pergelangan tangan memberikan hubungan yang signifikan dengan hasil pukulan servis pendek pada peserta ekstrakurikuler MTs Negeri 3 Kabupaten Sukabumi, yaitu sebesar 0,698 > Ftabel 3,11. Dengan demikian dapat disimpulkan bahwa pukulan servis pendek memerlukan fleksibilitas pergelangan tangan sebagai daya penggerak. Selain itu, fleksibilitas pergelangan tangan merupakan faktor utama untuk melakukan pukulan servis pendek secara akurat.

\section{Hubungan antara koordinasi mata tangan terhadap ketepatan pukulan servis pendek}

koordinasi mata tangan tidak kalah pentingnya dengan kontribusi fleksibilitas pergelangan tangan terhadap pukulan servis pendek. Koordinasi mata tangan memberikan nilai hubungan signifikansi sebesar 0,924 > Ftabel 3,11. Dengan demikian dapat disimpulkan bahwa pukulan servis pendek memerlukan konsentrasi koordinasi mata tangan yang baik sehingga menghasilkan pukulan yang melambung sedikit tinggi di atas net. Dengan kata lain, semakin baik koordinasi mata tangan maka akan semakin baik pukulan servis pendek yang dilakukan.

\section{Hubungan antara fleksibiltas pergelangan tangan dan koordinasi mata tangan terhadap ketepatan pukulan servis pendek}

Secara bersama-sama hubungan fleksibiltas pergelangan tangan dan koordinasi mata tangan dengan hasil ketepatan pukulan servis pendek tergolong kuat dan tinggi yaitu sebesar 0,927 > Ftabel 3,11 Hasil tersebut menunjukkan bahwa selain unsur-unsur kondisi fisik tersebut masih ada faktor-faktor lain yang mempengaruhi hasil pukulan servis pendek. Berdasarkan hasil perhitungan menggunakan teknik SPSS korelasi ganda diperoleh hasil bahwa Fhitung lebih besar dari pada Ftabel, yaitu Fhitung (39) > Ftabel $(3,11)$ dengan taraf signifikansi 0,05 maka H1 diterima artinya terdapat hubungan antara fleksibiltas pergelangan tangan dan koordinasi mata tangan terhadap ketepatan pukulan servis pendek dalam permainan bulutangkis pada peserta ekstrakurikuler MTs Negeri 3 Kabupaten Sukabumi.

Berdasarkan hasil korelasi X1, X2 terhadap Y, diperoleh Fhitung lebih besar dari pada Ftabel, yaitu Fhitung (39) > Ftabel $(3,11)$ dengan taraf signifikansi 0,05. Dengan mendapatkan hasil perhitungan RX1X2Y sebesar 0,927 dengan kategori tergolong kuat dan tinggi. Dan konstruksi secara simultan R2 x 100\% = 0,8592 x 100\% = 85,9\% dan sisanya 14,1\%. Artinya fleksibiltas pergelangan tangan dan koordinasi mata tangan memberikan kontribusi terhadap kemampuan pukulan servis pendek dalam permainan bulutangkis sebesar $85,9 \%$ dan sisanya $14,1 \%$ oleh variable lain.

Berdasarkan hasil korelasi X1, X2 terhadap Y, diperoleh Fhitung lebih besar dari pada Ftabel, yaitu Fhitung (39) > Ftabel $(3,11)$ dengan taraf signifikansi 0,05. Dengan mendapatkan hasil perhitungan RX1X2Y sebesar 0,927 dengan kategori tergolong kuat dan tinggi. Dan konstruksi secara simultan R2 x 100\% = 0,9272 × 100\% = 85,9\% dan sisanya 14,1\%. Artinya fleksibilitas pergelangan tangan dan koordinasi mata tangan memberikan kontribusi terhadap ketepatan pukulan servis pendek dalam permainan bulutangkis sebesar $85,9 \%$ dan sisanya $14,1 \%$ oleh variabel lain.

\section{Hubungan antara fleksibiltas pergelangan tangan dan koordinasi mata tangan terhadap ketepatan pukulan servis pendek}

Pada bagian pembahasan mengulas tentang hasil penelitian dan membandingkannya dengan berbagai teori serta penelitian yang relevan. Pada bagian ini disarankan untuk mengutip artikel sebanyak mungkin. 


\section{KESIMPULAN}

Berdasarkan hasil analisis data dan pembahasan maka kesimpulan dari penelitian ini, Pertama, Terdapat hubungan yang signifikan antara fleksibilitas pergelangan tangan terhadap ketepatan pukulan servis pendek dalam permainan bulutangkis pada peserta ekstrakurikuler MTs Negeri 3 Kabupaten Sukabumi. Kedua, Terdapat hubungan yang signifikan antara koordinasi mata tangan terhadap ketepatan pukulan servis pendek dalam permainan bulutangkis pada peserta ekstrakurikuler MTs Negeri 3 Kabupaten Sukabumi. Ketiga, Terdapat hubungan yang signifikan antara fleksibilitas pergelangan tangan dan koordinasi mata tangan terhadap ketepatan pukulan servis pendek dalam permainan bulutangkis pada peserta ekstrakurikuler MTs Negeri 3 Kabupaten Sukabumi

Berdasarkan hasil korelasi X1, X2 terhadap Y, diperoleh Fhitung lebih besar dari pada Ftabel, yaitu Fhitung (39) > Ftabel $(3,11)$ dengan taraf signifikansi 0,05. Dengan mendapatkan hasil perhitungan RX1X2Y sebesar 0,927 dengan kategori tergolong kuat dan tinggi. Dan konstruksi secara simultan R2 x 100\% = 0,9272 x 100\% = 85,9\% dan sisanya 14,1\%. Artinya fleksibilitas pergelangan tangan dan koordinasi mata tangan memberikan kontribusi terhadap ketepatan pukulan servis pendek dalam permainan bulutangkis sebesar $85,9 \%$ dan sisanya $14,1 \%$ oleh variabel lain.

\section{DAFTAR PUSTAKA}

1. (Producer). (2018). Ini Terobosan Baru di Audisi Umum Djarum Beasiswa Bulutangkis 2019. Retrieved from https://www.liputan6.com/bola/read/3639972/ini-terobosan-baru-diaudisi-umum-djarum-beasiswa-bulutangkis-2019

2. Aksan, H. (2012). Mahir bulutangkis. Bandung: Nuansa Cendekia.

3. Ardyanto, S. (2018). Peningkatan Teknik Servis Pendek Pada Bulutangkis Melalui Media Audio Visual. JURNAL ILMIAH PENJAS (Penelitian, Pendidikan dan Pengajaran), 4(3).

4. Atmojo, M. B. (2007). Tes \& Pengukuran Pendidikan Jasmani/Olahraga. In: Surakarta: UNS Press.

5. AZIZ, M. A. (2008). Perbedaan Latihan Pukulan Lob Berpola dan Latihan Pukulan Lob Bebas Tidak Berpola terhadap Hasil Pukulan Lob dalam Permainan Bulutangkis pada Atlet PB. Pendowo Semarang Tahun 2008. Universitas Negeri Semarang,

6. Dwiyogo, W. D. (2009). Olahraga dan pembangunan: WINEKA MEDIA

7. Ismaryati. (2011). tes dan Pengukuran Olahraga. Surakarta: Lembaga Pengembangan pendidikan (LPP) UNS dan UPT Penerbitan danpercetakan UNS.

8. Iswoyo, T., \& Junaidi, S. (2015). Sumbangan Keseimbangan, Koordinasi Mata Tangan Dan Power Lengan Terhadap Ketepatan Pukulan Boast Dalam Permainan Squash. Journal Of Sport Sciences And Fitness, 4(2).

9. Mardiana, A. (2014). Pendidikan jasmani dan olahraga.

10. Mujami, A. (2010). SUMBANGAN REAKSI DAN KELINCAHAN TERHADAP HASIL FOOTWORK PADA MAHASISWA IKK BULUTANGKIS I JURUSAN PENDIDIKAN KEPELATIHAN OLAHRAGA UNIVERSITAS NEGERI SEMARANG TAHUN 2009. Universitas Negeri Semarang,

11. Nala, N. (2011). Prinsip Pelatihan Fisik Olahraga. Denpasar. In: Udayana University Press. 
12. Qalbi, I., Abdurrahman, A., \& Bustamam, B. (2016). Hubungan Kelentukan Pergelangan Tangan dengan Kemampuan Servis Pendek pada Atlet UKM Bulutangkis Unsyiah Tahun 2016. Syiah Kuala University,

13. Riyadi, R. B. (2017). HUBUNGAN ANTARA KUANTITAS LATIHAN OLAHRAGA BULUTANGKIS DAN TINGKAT DEPRESI PADA USIA DEWASA. UNIMUS,

14. sport.tempo.com (Producer). (2019). BATC 2020: Tim Putri Indonesia Punya Peluang Kalahkan Thailand. Retrieved from https://sport.tempo.co/read/1306982/batc-2020-timputri-indonesia-punya-peluang-kalahkan-thailand/full\&view=ok

15. Sugiyono, P. (2015). Metode penelitian kombinasi (mixed methods). Bandung: Alfabeta.

16. Werdihartohadi, F. A. (2018). Menjadi Juara Bulutangkis: Be Champion.

17. .Yuliatin, E., \& Noor, M. (2012). Bugar dengan Olahraga: PT Balai Pustaka (Persero).

18. Yuliawan, D. (2017). Bulu tangkis dasar: Deepublish. 